\title{
Field Performance of Quercus bicolor Established as Repeatedly Air-Root-Pruned Container and Bareroot Planting Stock
}

\author{
J. W. Van Sambeek ${ }^{*}$, Larry D. Godsey ${ }^{2}$, William D. Walter ${ }^{3}$, Harold E. Garrett ${ }^{4}$, \\ John P. Dwyer ${ }^{5}$ \\ ${ }^{1}$ Northern Research Station, USDA Forest Service, University of Missouri, Columbia, MO, USA \\ ${ }^{2}$ Missouri Valley College, Marshall, MO, USA; formerly Center for Agroforestry, University of Missouri, \\ Columbia, MO, USA \\ ${ }^{3}$ College of Agriculture, Food, and Natural Resources, University of Missouri, Columbia, MO, USA \\ ${ }^{4}$ Center for Agroforestry, University of Missouri, Columbia, MO, USA \\ ${ }^{5}$ Department of Forestry, University of Missouri, Columbia, MO, USA \\ Email: "jvansambeek@fs.fed.us, godseyl@moval.edu, walterd@missouri.edu, \\ garretth@missouri.edu,dwyerj@missouri.edu
}

Received 27 April 2016; accepted 29 May 2016; published 2 June 2016

Copyright () 2016 by authors and Scientific Research Publishing Inc.

This work is licensed under the Creative Commons Attribution International License (CC BY). http://creativecommons.org/licenses/by/4.0/

(c) (i) Open Access

\section{Abstract}

Benefits of repeated air-root-pruning of seedlings when stepping up to progressively larger containers include excellent lateral root distribution immediately below the root collar and an exceptionally fibrous root ball. To evaluate long-term field performance of repeatedly air-root-pruned container stock, three plantings of swamp white oak (Quercus bicolor Willd.) 10 to 13 years old were located that also included bareroot planting stock. Initial and final stem diameter and height and above-ground green weights were determined on randomly selected trees at each site. On a site with a sandy, excessively drained, high $\mathrm{pH}$ soil, trees (age 10) from container stock were 1.5 times taller, 2.3 times larger in $\mathrm{dbh}$, and 2.8 times greater in green weight than trees from bareroot stock which averaged only $2.9 \mathrm{~m}$ tall, $3.9 \mathrm{~cm} \mathrm{dbh}$, and $16.3 \mathrm{~kg}$ green weight. On a site with high clay, poor internal drainage, and frequent flooding, trees (age 12) from container stock were 1.4 times taller, 1.8 times larger in $\mathrm{dbh}$, and 4.1 times greater in green weight than trees from bareroot stock which averaged $4 \mathrm{~m}$ tall, $7.3 \mathrm{~cm}$ dbh, and $28 \mathrm{~kg}$ green weight. On an upland site with deep loess soils, there was a trend for trees (age 13) from container stock to be only slightly larger than trees from bareroot stock with each stock type averaging $9.6 \mathrm{~m}$ tall, $20 \mathrm{~cm} \mathrm{dbh}$, and $177 \mathrm{~kg}$ green weight. Repeated air-root pruning produced lateral roots immediately below the root collar

${ }^{*}$ Corresponding author.

How to cite this paper: Van Sambeek, J. W., Godsey, L. D., Walter, W. D., Garrett, H. E., \& Dwyer, J. P. (2016). Field Performance of Quercus bicolor Established as Repeatedly Air-Root-Pruned Container and Bareroot Planting Stock. Open Journal of Forestry, 6, 163-176. http://dx.doi.org/10.4236/ojf.2016.63014 
that resulted in large container stock with large well-balanced root systems that were competitive on harsh or less than ideal oak sites. Although the process is relatively labor intensive, propagation of repeatedly air-root-pruned container stock is readily adaptable internationally to locally available sources of organic matter and open-bottom containers.

\title{
Keywords
}

\author{
Afforestation, Root Fibrosity, Root Production Method, Seedling Quality, Swamp White Oak, \\ Whole-Tree Biomass
}

\section{Introduction}

Although many technological advances have been made over the last twenty years in production of both bareroot nursery and container seedlings to improve planting stock quality, few studies have evaluated the long-term survival, growth, and economics of using these seedlings for the artificial regeneration of oak species. Although planting stock quality is difficult to quantify (Haase, 2008), the most reliable morphological indicator of quality and future survival and growth in the field continues to be basal stem diameter because it is highly correlated with many metrics of root system size (Davis \& Jacobs, 2005; Dey \& Parker, 1997; Tsakaldimi et al., 2013; Wilson \& Jacobs, 2006). Recent studies have shown that field performance of bareroot nursery stock can be improved by increasing the amount of organic matter in nursery beds (Davis et al., 2006) or decreasing seedling bed densities to produce larger seedlings (Schultz \& Thompson, 1996). Field performance has also been improved by undercutting or selecting seedlings for high numbers of lateral roots (Ruehle \& Kormanik, 1986; Schultz \& Thompson, 1990, 1996). Recently, Salifu et al. (2009) reported that nutrient loading of oak seedlings in the nursery had the potential to increase seedling performance especially on harsh or degraded sites.

Advances to improve performance of container hardwood stock have included using containers that are greater than 4.5 L in volume (Mariotti et al., 2015) and modified in design to increase seedling height to diameter ratios (Funk et al., 1980; Wood \& Hanover, 1981). Innovations in container design to reduce circling or spiraling roots include introduction of vertical ribs (Landis et al., 1990), copper coatings (Arnold \& Struve, 1989; Nelson, 1998; Struve, 1993), or use of side slits and open bottoms for air-root pruning of the taproot and lateral roots (Amoroso et al., 2010; Nelson, 1998; Rune, 2003; Mariotti et al., 2015). Higher quality container planting stock has also been achieved through modifications to potting medium including the addition of more organic constituents and hydrogel products, introduction of mycorrhiza, and fertilization protocols matched to seedling growth (Dixon et al., 1983; McDonald et al., 1984; Landis et al., 1990). The use of controlled-release fertilizers can both reduce nutrient leaching and contribute to nutrient loading of seedlings which has been shown to enhance survival and early growth especially on competitive sites (Haase et al., 2006; Salifu \& Jacobs, 2006; Timmer, 1996). Once seed stratification requirements have been met, container stock can be started in greenhouses thereby increasing the length of the growing season to produce larger seedlings. In addition, the importance of container stock will increase if methyl bromide is banned for use in bareroot nurseries (South, 2008).

More recent advances in production of container planting stock have included air-root-pruning approaches to improve lateral or feeder root distribution and their abundance immediately below the root collar. Whitcomb (2001) suggested that if these lateral roots were not forced shortly after germination, the opportunity was lost forever. Without early chemical- or air-root pruning, most primary and secondary lateral root tips are found at the bottom of the root plug with little root regeneration in the upper portions of the root system (Wenny \& Woolen, 1989). Approaches to force air-root pruning of the taproot and early lateral root initiation following germination include using small containers with side slits and open bottoms or shallow trays followed by the transplanting of seedlings through a series of increasingly larger containers (Lovelace, 1998, 2002; Whitcomb, 2001). Air-root-pruning approaches to increase seedling root size and density are especially well suited for oaks that produce multiple flushes because transplanting can be targeted for the lag phase when carbohydrates are actively being redistributed primarily to the roots.

Oak reforestation has been problematic because bareroot planting stock can be slow to establish and it com- 
petes poorly with herbaceous vegetation (Groninger, 2005; Stanturf et al., 2001, 2004). In addition, bottomland reforestation requires selecting oak species that exhibit tolerance to flooding and poorly-drained soils such as pin (Q. palustris Muenchh.), bur (Q. macrocarpa Michx.) and swamp white (Q. bicolor Willd.) oak (Kabrick et al., 2012). Of these, swamp white is important for artificial regeneration to restore timber and wildlife mast on uplands and floodplains throughout much of the northeastern US (Rogers, 1990). Commercially, wood of swamp white oak is not distinguished from that of white oak (Q. alba L.) (Kurz, 2003). Side-by-side comparisons of bareroot and air-root-pruned container seedlings of swamp white oak have shown container planting stock can outperform bareroot nursery stock on bottomland sites during the establishment phase (Dey et al., 2004; Kabrick et al., 2005); however, it is unclear how long the superior growth performance will persist.

Future oak restoration is expected to shift toward harsh, degraded environments (Oliet \& Jacobs, 2012). Landhausser et al. (2012) found differences in field performance among planting stock types tend to be most strongly expressed when seedlings were exposed to stressful site conditions. In this article, we report on the field performance of swamp white oak ten to thirteen years after planting where both air-root-pruned container and bareroot planting stock had been planted on harsh or less than ideal oak sites.

\section{Methods}

For this study, we were able to locate only three hardwood plantings that were 10 years old or older where both repeatedly air-root-pruned container $\left(\mathrm{RPM}^{\circledR}\right.$, Forrest Keeling Nursery, Elsberry, MO) and nursery-grown bareroot planting stock had been established. In addition, swamp white oak was the only species in common at plantings established at the Plowboy Bend Conservation Area (CA), the Cuivre Island CA, and the Horticulture and Agroforestry Research Center (Figure 1). The long-term annual precipitation for all three study sites is 965 $\mathrm{mm}$ with more than $60 \%$ falling during the growing season. The mean daily temperature is $-3^{\circ} \mathrm{C}$ in January and $25^{\circ} \mathrm{C}$ in July. Unless otherwise noted, each planting site was mowed and plowed or disked to kill perennial vegetation, soils were mounded, and the area seeded to redtop grass(Agrostis gigantean Roth) before planting tree seedlings.

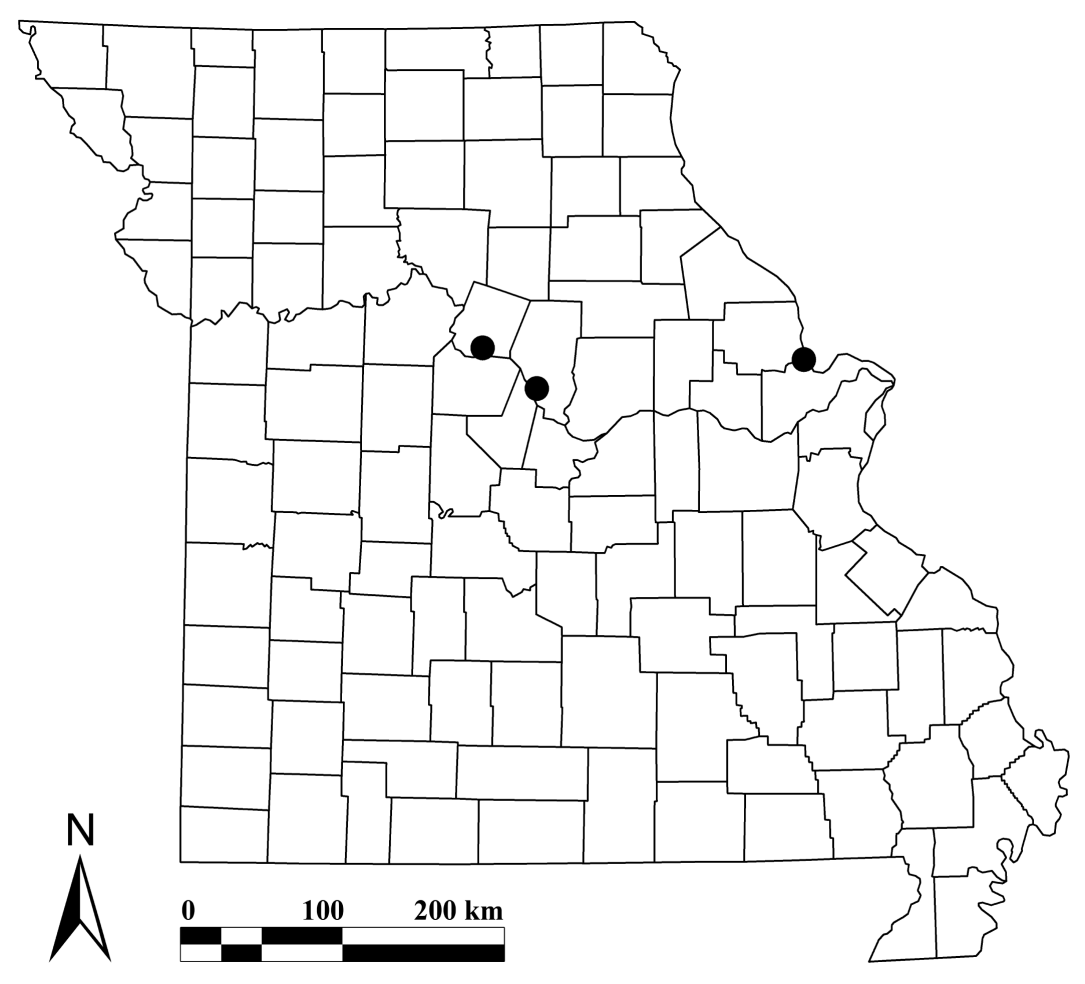

Figure 1. Map of Missouri by counties showing planting location for the Plowboy Bend Conservation Area (center dot), the Cuivre Island Conservation Area (right dot), and the Horticulture and Agroforestry Research Center (left dot) study sites established with both RPM container and bareroot planting stock of swamp white oak. 


\subsection{Plowboy Bend Conservation Area (CA)}

Details for establishment of the bottomland planting at the Plowboy Bend CA are described in Dey et al. (2004) and Kabrick et al. (2005). Briefly, this planting was established on a sandy, excessively drained soil located in the Missouri River floodplain in Moniteau County, Missouri (3848'N, 92 ${ }^{\circ} 24^{\prime} \mathrm{W}$; $172 \mathrm{~m}$ elev.). Soils are mapped as Lowmo silt loam (Coarse-silty, mixed, superactive, mesic Fluventic Hapludolls), Treloar-Sarpy-Kenmoor soils (Sandy over loamy, mixed, superactive, calcareous, mesic Oxyaquic Udifluvents; Mixed, mesic Typic Udipsamments; and Sandy over clayey, mixed, superactive, calcareous, mesic Oxyaquic Udifluvents, respectively), and Buckney fine sandy loam (Sandy, mixed, mesic Typic Hapludolls). These soils are formed in sandy alluvium and have a high $\mathrm{pH}$ (7.8 to 8.3). The water table is generally more than $1.5 \mathrm{~m}$ below the surface. The area is protected by a 100-year flood levee and has not been flooded since the planting was established.

At the Plowboy Bend CA site, flat-crowned soil berms were constructed in September 1999 after the August tillage with a levee plow (AMCO LF6-824, AMCO Manufacturing, Inc., Yazoo City, MS). Berms running the length of the planting measured essentially 1-m wide at the top by 2-m wide at the base, averaged $30 \mathrm{co} 40 \mathrm{~cm}$ in height, and were spaced $9.1 \mathrm{~m}$ apart, center-to center. Container stock was shovel-planted without vertical slicing or scalping of root plugs in November 1999 down the middle of five adjacent raised berms at $9.1 \mathrm{~m}$ intervals. Bareroot seedlings were shovel-planted in contiguous plots along the same berms in March 2000. Both seedling types were planted with root collars $2 \mathrm{~cm}$ below the soil surface. A 1.2-m square, water-permeable, polypropylene weed barrier mat (Nursery Products ${ }^{\circledR}$ Tree Squares) was placed around each seedling in the spring and anchored with 15-cm long wire staples. After all seedlings were planted and each spring thereafter for two years, $30 \mathrm{~g}$ of controlled-release 33-3-6 NPK fertilizer (Scotts ${ }^{\circledR}$ Osmocote Classic) was broadcast over the weed barrier fabric placed around each tree.

\subsection{Cuivre Island Conservation Area (CA)}

The hardwood planting at Cuivre Island CA in St. Charles County, Missouri (3854'N, 9040'W; $160 \mathrm{~m}$ elev.) was established in 1998 on a high clay, poorly drained soil with frequent flooding. The site is located in the Mississippi River floodplain. The soils are Carlow silty clay loam (fine smectic, mesic Vertic Endoaquolls) with a 1\% slope. These soils formed in clayey alluvium, have high runoff, and poor internal drainage. The planting was flooded nine times between 1998 and 2010 by spring floods of one- to four-week durations.

At the Cuivre Island CA site, soil mounds spaced $9.1 \mathrm{~m}$ apart, center-to-center, were constructed in September 1997 with a levee plow before seeding to redtop grass. Container stock was shovel-planted in October/November 1997 down the middle of mounds on 9.1-m centers. Bareroot seedlings obtained from the George O. White State Nursery were shovel-planted in late-March 1998 down the middle of the mounds between the fallplanted container seedlings. A 1.2-m square polypropylene weed barrier mat was placed around each seedling in the spring and anchored. After all seedlings were planted and in the spring for the next two years, $30 \mathrm{~g}$ of controlled-release 33-3-6 NPK fertilizer was broadcast over the weed barrier mat of each tree.

\subsection{Horticulture and Agroforestry Research Center (HARC)}

The hardwood planting at the Horticulture and Agroforestry Research Center (HARC) in Howard County, Missouri (39 $01^{\prime} \mathrm{N}, 92^{\circ} 45^{\prime} \mathrm{W}$; $197 \mathrm{~m}$ elev.) was established in 1997 on an upland pasture with deep loess soils. The soils are Menfro silt loam (fine-silty, mixed superactive, mesic Typic Hapludalfs) with a 2\% slope. In August 1996, 1.5-m-wide strips on 6-m centers were sprayed with a combination of glyphosate $\left(2.6 \mathrm{~kg} \cdot \mathrm{ha}^{-1}\right) \mathrm{and} \mathrm{sima-}^{-}$ zine (4.4 kg·ha ${ }^{-1}$ ) to kill and prevent regrowth of tall fescue grass (Schedonorus arundinaceus (Schreb.) Dumart). A 1.2-m wide roll of polypropylene weed barrier mat (DeWitt ${ }^{\circledR}$ Pro 5) was placed down the middle of each strip in September 1996. Pairs of container-grown seedlings were shovel-planted in late fall 1996 and pairs of bareroot seedlings were shovel-planted in mid-March 1997 down three 48-m long rows with 3 m between seedlings. Narrow strips along both sides of the weed mat were maintained free of vegetation with the use of glyphosate as needed throughout the study (1997 to 2010), which were gradually widened to $2 \mathrm{~m}$. All surviving trees were measured in 2010 and a subsample was harvested as part of a thinning operation for our study.

\subsection{Air-Root-Pruned Container Seedling Production}

For the above plantings, acorns were collected from a single tree in the fall of 1995 and from a stand of trees 
growing along the Cuiver River in St. Charles County, Missouri and Lincoln County, Illinois in the fall of 1996 and 1998. After soaking acorns for 24 hours, only the acorns that sank were retained and allocated into two equal lots each year. One lot of acorns was placed in plastic bags and stored under moist conditions at $1^{\circ} \mathrm{C}$ in a walk-in cooler at the Forrest Keeling Nursery (Elsberry, MO; $39^{\circ} 08^{\prime} \mathrm{N}, 90^{\circ} 47^{\prime} \mathrm{W}, 164 \mathrm{~m}$ elev.). Acorns in the other lot were immediately sown across the surface of 37- $\times 47-\times 6$-cm molded polystyrene mesh flats. Flats were filled to within $1 \mathrm{~cm}$ of the top with a potting mixture of composted rice hulls, pine bark, and sand (4:4:2 by volume), amended with controlled-release 22-3-8 NPK fertilizer (Scotts ${ }^{\circledR}$ Osmocote Classic), micronutrients $\left(\right.$ Scotts Micromax ${ }^{\circledR}$ ), mycorrhizal spores, and a wetting agent (Terra-Sorb ${ }^{\circledR}$ Coarse) creating a growth medium with a 35\% to $40 \%$ air pore volume. Trays were stacked inside a walk-in cooler and periodically watered to keep the medium moist. Production of large air-root-pruned container seedlings for this study followed the patented nursery cultural system known as the Root Production Method $\left(\mathrm{RPM}^{\circledR}\right)$ developed by the Forrest Keeling Nursery which reserves the right to use this registered name (Lovelace, 1998, 2002).

During early February, flats were removed from the coolers and placed in a heated greenhouse on wire benches. After the first flush of growth was completed, the largest and fastest growing seedlings (essentially half the seedlings) with 5-cm long air-root-pruned taproots and well-developed first-order lateral roots immediately below the root collar were transplanted into square 7- $\times 7-\times 14-\mathrm{cm}$ plastic band containers in 1996 or square 10$\times 10-\times 9.5-\mathrm{cm}$ band containers in 1997 and 1999 with the same 4:4:2 potting medium. The seedlings were grown through two flushes (essentially 60 days) in these open bottom containers placed in open mesh flats set on wire benches. Air pruning of the taproot(s) and first-order lateral roots produced a dense mass of fine roots during this time (Figure 2). In early May of each year, seedlings were moved out of the greenhouse and placed under mist for 48 hours. Seedlings were then transplanted without further air-root pruning into 10-L round polyethylene squat pots (26-cm wide x 18-cm deep; Custom \#2+ Squat, Nursery Supplies, Chambersburg, PA) filled with the same 4:4:2 potting medium and placed pot-to-pot under overhead mist irrigation on white gravel beds under full sun for the remainder of their 210-day growing season. Container stock was shipped to the planting sites without sizing in 1996; however, in 1997 and 1999, only the largest 20\% of the stock was shipped to meet contractor specifications of a stem height $>150 \mathrm{~cm}$ and a stem caliper $>15 \mathrm{~mm}$.

\subsection{Bareroot Seedling Production}

In the fall of 1995 and 1998, acorns that had been placed in plastic bags and stored for 4 weeks in the walk-in cooler were sown at a nominal 200 acorns $\cdot \mathrm{m}^{-2}$ in a conventional nursery bed at the Forrest Keeling Nursery. Nursery beds were covered with $5 \mathrm{~cm}$ of mulch during overwinter stratification. Before 1.2-m wide raised nursery beds were created, $1000 \mathrm{~kg} \cdot \mathrm{ha}^{-1}$ of 28-14-14 NPK fertilizer was tilled into the silty loam soil. An additional

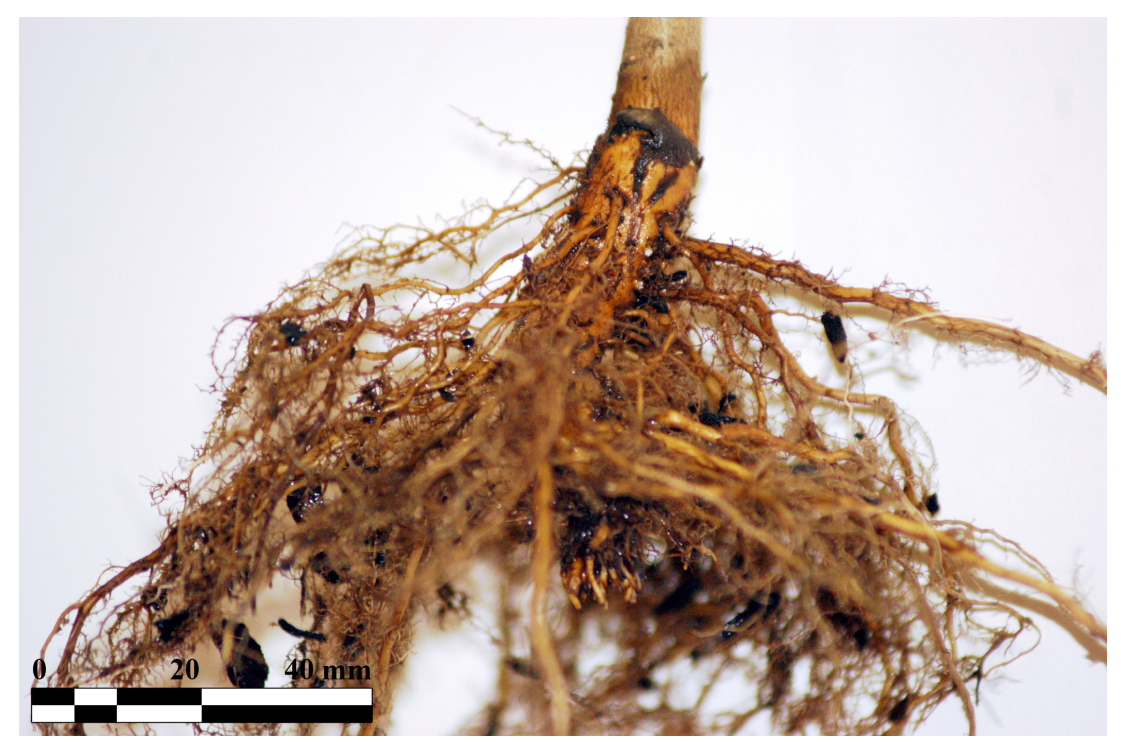

Figure 2. Roots of a swamp white oak seedling after having been stepped up to a $1 \mathrm{~L}$ pot with air-root-pruned taproot(s) and extensive development of many first-order lateral roots along the taproot immediately below the root collar. 
1000 to $1500 \mathrm{~kg} \cdot \mathrm{ha}^{-1}$ of the same fertilizer was applied in increments of 300 to $400 \mathrm{~kg} \cdot \mathrm{ha}^{-1}$ during the remainder of the growing season. Seedlings were lifted in late February through early March of the following year and stored at $1^{\circ} \mathrm{C}$ under moist, humid conditions until shipped for field planting. In spring of 1998, bareroot planting stock was obtained from the George O. White State Nursery in Licking, MO (37 $33^{\prime} \mathrm{N}, 9^{\circ}{ }^{\circ} 53^{\prime} \mathrm{W}$; $357 \mathrm{~m} \mathrm{elev}$.) that had been grown with nursery practices similar to those at the Forrest Keeling Nursery.

\subsection{Data Collection and Analyses}

During February 2010, up to 29 trees established as either container or bareroot planting stock at each of the three study sites were measured for height and diameter at breast height (dbh) and a subset marked for destructive harvesting. At Plowboy Bend CA, 29 trees from container stock were randomly selected from mounded rows and paired with trees established as bareroot stock in an adjacent mounded plot for height and dbh measurements. Only trees from one-year-old bareroot or air-root-pruned container seedlings established on mounds in the area seeded to redtop grass were used in our study to minimize confounding effects of animal damage and planting stock age across study sites (Dey et al., 2004). Sixteen of the 29 pairs of trees were randomly selected for destructive harvesting. At the Cuivre Island CA, 25 trees from container stock were randomly selected from across the planting and paired with the nearest tree established as a bareroot seedling for height and dbh measurements. Ten pairs of these trees were randomly selected for destructive harvesting. At the HARC site, all surviving trees of each planting stock type were measured for height and dbh; however, only ten trees of each planting stock type were made available for destructive harvesting when the planting was thinned.

Height and dbh were taken on the standing trees using a laser rangefinder (Impulse 200, Laser Technology Inc., Centennial, CO) and diameter tape, respectively. Initial height and basal caliper of the same trees were determined from archived planting records. Trees destructively harvested during the dormant season were cut at ground line and the dbh, height, and above-ground green weights were measured. Whole-tree and stem-only green weights were determined immediately after cutting using a 450-kg load cell (Dillon SGCN, Dillon Force Measurement Equipment, Fairmont, MN) hung from the bucket of a skid loader.

Because two of the three study sites had been established as mixed plantings without blocking and had noticeable differences in tree height across the sites, data for each site were analyzed separately. Trees from container stock at each site were paired with the nearest tree established as a bareroot seedling. A paired t-test was used to determine significance of differences $(p=0.05)$ for initial seedling height and stem caliper, final height and dbh, and whole-tree and stem-only green weight at each site.

\section{Results}

\subsection{Plowboy Bend CA}

After 10 years, swamp white oak trees established as air-root-pruned container planting stock were 1.5 times taller, 2.2 times larger in dbh, and had 2.8 times greater whole-tree and stem-only green weights than trees from bareroot planting stock (Table 1). At outplanting, the container planting stock was 4.5 times taller and 2.5 times

Table 1. Means and standard deviations for $10^{\text {th }}$-year and outplanting measurements of swamp white oak established at the Plowboy Bend Conservation Area study site.

\begin{tabular}{|c|c|c|c|c|c|}
\hline \multirow{2}{*}{ Measurement } & \multirow{2}{*}{ No. Pairs } & \multicolumn{2}{|c|}{ Planting Stock Type } & \multirow{2}{*}{ t-value } & \multirow{2}{*}{$P$-value } \\
\hline & & Container & Bareroot & & \\
\hline Height (m) & 29 & $4.41 \pm 1.16$ & $2.90 \pm 1.33$ & 6.11 & $<0.001$ \\
\hline $\mathrm{DBH}(\mathrm{cm})$ & 29 & $8.8 \pm 3.2$ & $3.9 \pm 3.0$ & 8.37 & $<0.001$ \\
\hline \multicolumn{6}{|l|}{ Green weight (kg): } \\
\hline Stem-only & 16 & $22.8 \pm 14.3$ & $8.1 \pm 7.3$ & 4.48 & $<0.001$ \\
\hline Whole-tree & 16 & $45.2 \pm 29.8$ & $16.3 \pm 14.4$ & 4.28 & $<0.001$ \\
\hline Initial height ${ }^{\mathrm{b}}(\mathrm{cm})$ & 29 & $189.6 \pm 30.6$ & $42.2 \pm 32.6$ & 24.29 & $<0.001$ \\
\hline Basal caliper $^{\mathrm{b}}$ (mm) & 29 & $17.3 \pm 2.9$ & $6.8 \pm 1.6$ & 17.08 & $<0.001$ \\
\hline
\end{tabular}

${ }^{\mathrm{a}} \mathrm{P}$-values are based on paired t-tests matching indicated number of trees from the repeatedly air-root-pruned container planting stock to the nearest tree planted as a bareroot seedling within this planting. ${ }^{\mathrm{b}}$ Initial height and basal caliper were measured on both stocktypes in the spring after planting the bareroot planting stock. 
larger in basal caliper than the bareroot planting stock. Shaw et al. (2003) reported that the root systems on the year-old container oak seedlings planted at this site weighed $64 \mathrm{~g}$ with a volume of $140 \mathrm{~cm}^{3}$ compared to only $21 \mathrm{~g}$ and $33 \mathrm{~cm}^{3}$ for the bareroot planting stock (Figure 3). Although the bareroot stock was some of the largest swamp white oak seedlings produced at the nursery in 1999, their small size would indicate they were grown at relatively high seedling densities. Survival was not evaluated in our study; however, Dey et al. (2004) reported high seedling survival rates (>95\%) for both the bareroot and container planting stock after the first year followed by heavy mortality for the bareroot stock reducing survival to 80 and $75 \%$ in the second and third year, respectively, while survival of the container planting stock remained high (>95\%).

\subsection{Cuivre Island CA}

After 11 years, swamp white oak trees established as air-root-pruned container planting stock were 1.4 times taller and had 1.8 times greater dbh than trees from the bareroot planting stock (Table 2). More importantly, whole-tree and stem-only green weights were 4.1 times and 3.5 times greater, respectively, for the trees from the container stock than from the bareroot planting stock. Although both stock types were heavily graded to meet minimum size requirements as specified in the cost-share agreement to establish the planting, the container planting stock was more than 3 times larger for both height and basal caliper than the bareroot planting stock that came from the state-run nursery. At both the Plowboy Bend CA and Cuivre Island CA, the trees from container stock had a greater percentage change in diameter growth than height growth and lower height-to-diameter ratios (50:1 and 43:1 for container and 74:1 and 55:1 for bareroot planting stock at Plowboy Bend CA and Cuivre Island CA, respectively) than the trees from the bareroot stock. Because root growth is highly correlated with diameter growth, the changes in height-to-diameter ratios indicate the container planting stock also had greater root growth. Although no swamp white oaks were excavated at either site, an excavated four-year-old sapling of northern red oak (Q. rubra L.) showed extensive root development and persistence for many of the lateral and multiple taproots initiated during air-root pruning (Figure 4).

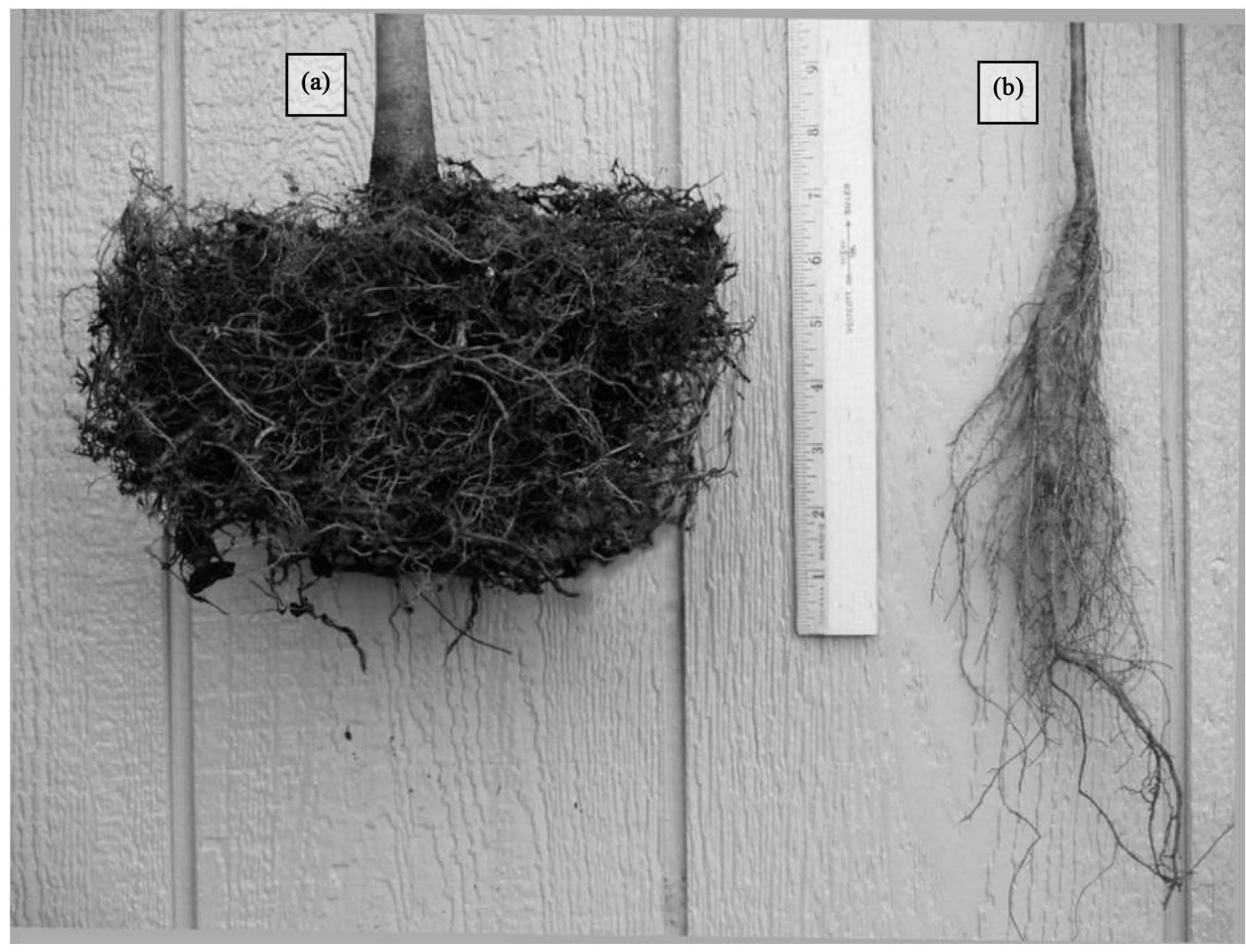

Figure 3. Comparison of root development after one growing season in the nursery between repeatedly air-root-pruned container-grown (a) and bareroot nursery-grown (b) seedlings of swamp white oak (ruler length is $24 \mathrm{~cm}$ ). 


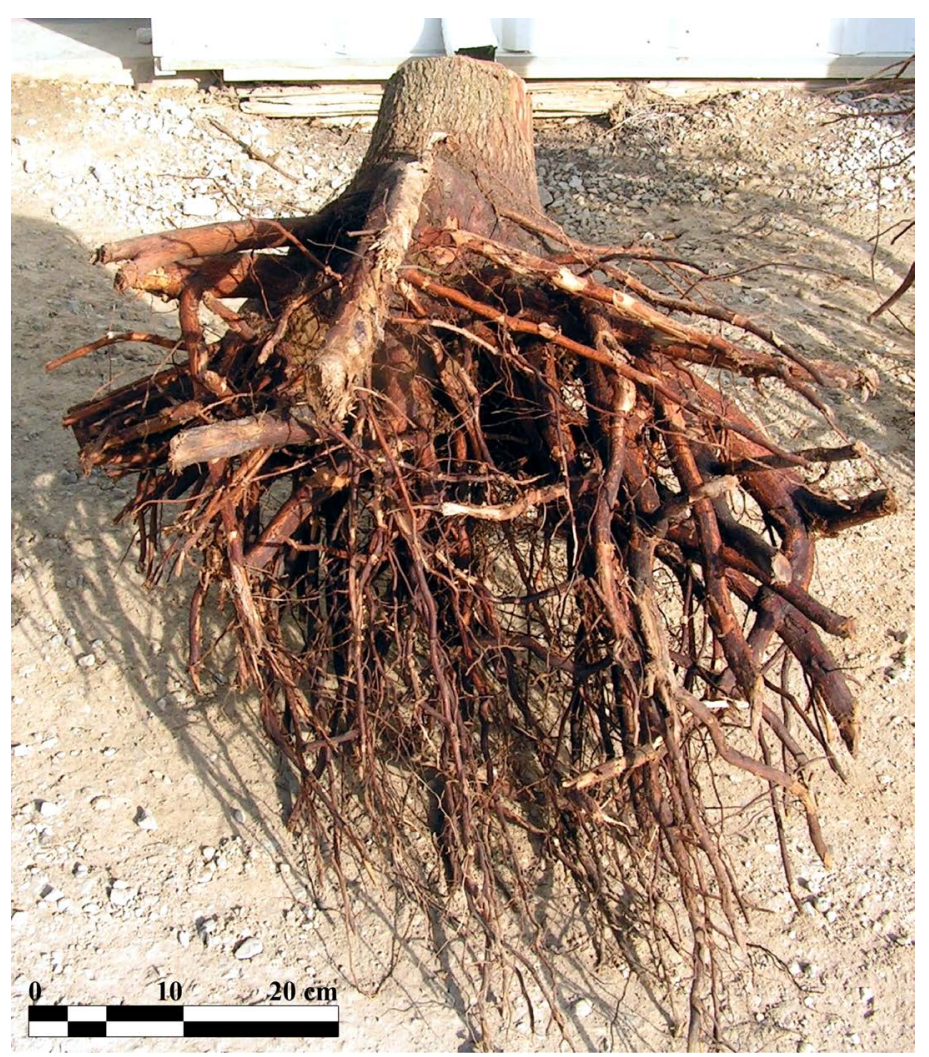

Figure 4. Root architecture of a 4-year-old northern red oak sapling established as a repeatedly air-root-pruned containergrown seedling showing extensive development of horizontal lateral roots near the soil surface and multiple verticallyoriented taproots.

Table 2. Means and standard deviations for $12^{\text {th }}$-year and outplanting measurements of swamp white oak established at the Cuivre Island Conservation Area study site.

\begin{tabular}{|c|c|c|c|c|c|}
\hline \multirow{2}{*}{ Measurement } & \multirow{2}{*}{ No. Pairs } & \multicolumn{2}{|c|}{ Planting Stock Type } & \multirow{2}{*}{ t-value } & \multirow{2}{*}{$P$-value } \\
\hline & & Container & Bareroot & & \\
\hline Height (m) & 25 & $5.70 \pm 1.19$ & $4.02 \pm 1.04$ & 6.53 & $<0.001$ \\
\hline $\mathrm{DBH}(\mathrm{cm})$ & 25 & $13.3 \pm 2.6$ & $7.3 \pm 2.9$ & 7.70 & $<0.001$ \\
\hline \multicolumn{6}{|l|}{ Green weight (kg) } \\
\hline Stem-only & 10 & $51.9 \pm 12.3$ & $15.0 \pm 7.5$ & 16.36 & $<0.001$ \\
\hline Whole-tree & 10 & $118.3 \pm 32.5$ & $27.9 \pm 15.4$ & 12.14 & $<0.001$ \\
\hline Initial height ${ }^{\mathrm{b}}(\mathrm{cm})$ & 25 & $178.3 \pm 21.3$ & $48.6 \pm 34.0$ & 18.19 & $<0.001$ \\
\hline Basal caliper $^{\mathrm{b}}(\mathrm{mm})$ & 25 & $26.6 \pm 4.5$ & $8.4 \pm 2.3$ & 16.96 & $<0.001$ \\
\hline
\end{tabular}

${ }^{\mathrm{a}} \mathrm{P}$-values are based on paired t-tests matching indicated number of trees from repeatedly air-root-pruned containerplanting stock to the nearest tree planted as a bareroot seedlings within this planting. ${ }^{b}$ Initial height and basal caliper were measured on both stocktypes in the spring after planting the bareroot planting stock.

\subsection{Horticulture and Agroforestry Research Center}

After 13 years, swamp white oak trees established as air-root-pruned container planting stock had 1.1 times greater dbh than trees from bareroot planting stock (Table 3). Although not statistically significant, trees from the container planting stock tended to be slightly taller and had 1.1 times greater whole-tree and stem-only green weights than trees from the bareroot planting stock. The container stock when outplanted had a basal caliper and 
Table 3. Means and standard deviations for 13th-year and outplanting measurements of swamp white oak established at the Horticulture and Agroforestry Research Center study site.

\begin{tabular}{|c|c|c|c|c|c|}
\hline \multirow{2}{*}{ Measurement } & \multirow{2}{*}{ No. Pairs } & \multicolumn{2}{|c|}{ Planting Stock Type } & \multirow{2}{*}{ t-value } & \multirow{2}{*}{$P$-value ${ }^{\mathrm{a}}$} \\
\hline & & Container & Bareroot & & \\
\hline Height (m) & 24 & $9.71 \pm 0.89$ & $9.50 \pm 0.97$ & 1.21 & 0.238 \\
\hline Dbh (cm) & 24 & $21.3 \pm 3.5$ & $19.8 \pm 2.5$ & 2.22 & 0.036 \\
\hline \multicolumn{6}{|l|}{ Green weight (kg): } \\
\hline Stem-only & 10 & $124 \pm 32$ & $109 \pm 27$ & 1.40 & 0.194 \\
\hline Whole-tree & 10 & $185 \pm 56$ & $171 \pm 55$ & 0.73 & 0.482 \\
\hline Initial height $^{\mathrm{b}}(\mathrm{cm})$ & 24 & $83.3 \pm 13.1$ & $27.0 \pm 8.2$ & 32.65 & $<0.001$ \\
\hline Basal caliper $^{\mathrm{b}}$ (mm) & 24 & $8.4 \pm 1.0$ & $4.5 \pm 1.2$ & 15.78 & $<0.001$ \\
\hline
\end{tabular}

${ }^{\mathrm{a} P} \mathrm{P}$-values are based on paired t-tests matching indicated number of trees from repeatedly air-root-pruned container planting stock to the nearest tree planted as a bareroot seedling within this planting. ${ }^{b}$ Initial height and basal caliper were measured on both stocktypes in the spring after planting the bareroot planting stock.

height which was more than 3 times greater than that of the bareroot planting stock. The small size of the bareroot planting stock (27-cm tall and 4.5-mm stem caliper) is probably the result of growing at relatively high seedling densities in the nursery beds with 200 acorns $\mathrm{m}^{-2}$ sowing rates. The larger size of the container stock at Plowboy Bend and Cuivre Island CA than at the Horticulture and Agroforestry Research Center is a function of scaling up of first flush seedlings to a slightly larger plant band container $(0.7$ to $1.0 \mathrm{~L})$ and the heavier grading of the planting stock for the 1997 and 1999 plantings. Even with this change, less than 20\% of the container seedlings in 1997 and 1999 exceeded a minimum height $>150 \mathrm{~cm}$ and basal caliper $>15 \mathrm{~mm}$.

\section{Discussion}

It is relatively well documented that differences in field performance among planting stock types are more strongly expressed when seedlings are exposed to stressful site conditions (Landhausser et al., 2012; Oliet \& Jacobs, 2012; Pinto et al., 2011). Pinto et al. (2011) also reported that growth differences among containergrown stock types persisted longer than differences among bareroot stock types especially on xeric sites where absolute growth was reduced for all stocktypes. Our results support the above findings with long-term differences in tree growth between the repeatedly air-root-pruned container and the bareroot planting stock still evident on a drought site (Plowboy Bend CA) and a frequently flooded poorly-drained site (Cuiver Island CA) but not on an excellent oak site (HARC). The latter site has a deep loess upland soil ideally suited for growing oak and other mesic hardwoods. With excellent grass control, oak seedlings of both stocktypes were relatively free to grow with little competition or shading during establishment. Responses, however, can be species specific because Walter et al. (2013) reported significantly greater growth for air-root-pruned container than for bareroot stock of white oak and black oak (Q. velutina Lam.) but not for swamp white oak at the HARC site.

Oliet and Jacobs (2012) comment that the current focus for regeneration has shifted prominently toward restoration of harsh degraded environments and this demands development of new seedling production and planting techniques. Planting large repeatedly air-root-pruned container seedlings appears to be worthy of consideration, especially on harsh sites. Several reasons can be suggested as to why the container stock outperformed the bareroot planting stock on the less than ideal oak sites in our study. The container stock had basal calipers at planting 2.5 to 3 times larger than the bareroot stock of the same age (Tables 1-3). Tsakaldimi et al. (2013) found that basal caliper was the variable that most accurately predicted survival of five tree species in Mediterranean restoration plantings. Davis and Jacobs (2005) reported that field performance of oak seedlings was positively correlated with large root volumes, high root fibrosity, and an increase in number of first-order lateral roots (FOLR).The repeatedly air-root-pruned container planting stock was superior in all three morphological measures of planting stock quality compared to the bareroot planting stock. Although it is unclear if there is a limit to how many FOLRs maximize this response, container seedlings used in this study far exceeded the number of FOLRs reported for even the best bareroot seedlings (Figure 3) produced at conventional nurseries with 
or without undercutting (Schultz \& Thompson, 1990).

Successful seedling establishment is partially dependent on the capacity of seedlings to initiate new roots quickly and establish a vigorous root system before initiation of rapid new shoot growth (Rietveld \& Van Sambeek, 1989; Grossnickle, 2005). Unlike bareroot or small container planting stock, the air-root-pruned container stock can be fall-planted with minimal risk of frost heaving (Van Sambeek et al., 1987). In addition with air-root pruning, root tips are suberized and are ready to grow immediately unlike the bareroot seedlings that must regenerate new roots following planting (Arnold \& Strueve, 1989; Landis et al., 1990). It is likely that our fallplanted repeatedly air-root-pruned seedlings also were putting on new root growth during the dormant season, while the bareroot seedlings were still in storage, and making them more tolerant of spring flooding or summer droughts.

We hypothesize the trees from container planting stock had more rapid sustained growth than the bareroot counterparts at both the Plowboy Bend CA and Cuivre Island CA for several reasons. During production of repeatedly air-root-pruned container stock, seed and seedlings are graded multiple times to select for heavy seed and the largest most vigorous seedlings (Grossman et al., 2003). Extensive culling of seedlings each time they are transplanted (stepped up) into increasingly larger containers includes selecting seedlings for size as well as the abundance of lateral roots near the root collar. Bumgarner et al. (2008) and Goransson et al. (2007) showed that the production of feeder roots near the root collar improved seedling establishment and early growth in the field because these roots are better distributed where soil nutrients are concentrated.

Fall nutrient loading also has been shown to improve seedling growth after planting especially on harsh or less than ideal planting sites (Haase et al., 2006; Timmer, 1996). The key to successful nutrient loading is the use of balanced fertilizers, where 1.3 to $1.7 \mathrm{~g} \cdot$ plant $^{-1}$ of $\mathrm{N}$ optimizes the response for bareroot oak seedlings (Salifu et al., 2009). The fertilization program for production of our bareroot seedlings is estimated to be essentially $1 \mathrm{~g} \cdot$ plant $^{-1}$ of $\mathrm{N}$ of which most is made available early in the growing season. In contrast, air-root-pruned container stock was supplied with 2.9 to 3.8 times more $\mathrm{N}$ with the majority being made available during the last half of the growing season when stepped up from 1-L open-bottom pots to 10-L pots.

Redtop grass was established in the Plowboy Bend CA and Cuivre Island CA plantings. Once established, this cool-season perennial grass can essentially exclude most other vegetation present in the seedbank from emerging, thus minimizing overtopping and shading of the planted oak seedlings (Dey et al., 2004). As a ground cover, Van Sambeek and Garrett (2004) report redtop grass may be one of the least competitive grass cover crops for use in tree plantings. As a cool-season forage that produces thin stands, it competes less for available water than most other forage grasses. Our results suggest the extensive feeder root systems on the container planting stock may have been more effective than the deeper roots of bareroot seedlings at competing with the grass roots for water and nutrients that leached through the weed barrier mats.

Addition of the potting medium in the planting hole when planting the container stock also increased availability of soil micronutrients which can be limiting on alkaline soils. Ponder Jr. et al. (2008) found that foliage concentrations for most of the micronutrients in pin and swamp white oak saplings established as container stock on alkaline soils $(\mathrm{pH}>8)$ were at the low end of the sufficiency range during the first growing season and declined to below the sufficiency level during the second growing season. Chemical analyses of the potting medium used in our study which contained controlled-release micronutrients revealed that only manganese and sulfur concentrations would have been reduced to less than half the initial concentrations before field planting. The potting medium was likely a significant source of micronutrients during field establishment for container planting stock in the deep sandy alluvium at the Plowboy Bend CA.

It is also well documented that larger planting stock will usually outperform smaller planting stock of the same age. Although both the repeatedly air-root-pruned container and bareroot swamp white oak seedlings in our study had been grown in the nursery for one year, the container stock was nearly 3 times taller and larger in basal caliper than the bareroot planting stock (Tables 1-3). There is no one single reason for differences in size. Initiating acorn germination in flats in the greenhouse in early February added nearly two months to the growing season for the container planting stock. The potting medium used is much higher in organic matter and has a greater air pore volume (40\%) than the soils in the nursery beds. Davis et al. (2006) found adding relatively high additions of organic matter to nursery soils produced larger seedlings with larger root volumes although the response was strongly dependent on the type and quantity of the materials used. Jacobs and Landis (2009) indicated that nitrogen was often the nutrient limiting seedling growth in nurseries. At the Forrest Keeling Nursery, bareroot seedlings were supplied with essentially $1 \mathrm{~g} \mathrm{~N} \cdot$ plant $^{-1}$ in the nursery bed through the growing season 
$\left(3500 \mathrm{~kg} \cdot \mathrm{N} \cdot \mathrm{ha}^{-1}\right)$. In contrast, container seedlings were supplied with more than $3 \mathrm{~g} \cdot \mathrm{plant}^{-1}$ of controlled-re- $^{-}$ leased $\mathrm{N}$ in essentially $10 \mathrm{~L}$ of potting medium. Much of it made available late in the growing season as seedlings were stepped up into larger containers. Air-root pruning of the taproot at $<6 \mathrm{~cm}$ produced a profusion of finely branched lateral (feeder) roots heavily colonized by ectomycorrhizal fungi that had been incorporated into the potting medium. In contrast, bareroot planting stock was only lightly colonized by ectomycorrhizal fungi introduced into the nursery beds through air-borne spores or from below the sterilized soil.

\section{Economic Considerations and Implications}

Dey et al. (2008) indicated that trade-offs between seedling size, planting density, and planting costs determine the appropriate least-cost approach to attaining some target stocking goal. Although the stocking goal is relatively clear when planting hardwoods into natural stands, it is less clear what it should be under afforestation or plantation settings. One approach for setting a stocking goal when using container or bareroot planting stock is estimating the number of seedlings that need to be planted to have a threshold number of trees greater than an acceptable size at some point during the rotation such as 300 trees $^{-h^{-1}}{ }^{-1}$ with a dbh $>6 \mathrm{~cm}, 10$ years after planting. To reach a harvestable size of $48 \mathrm{~cm}$ within 80 years, trees must annually average $6 \mathrm{~mm}$ of diameter growth. All trees at the HARC site had annual growth rates exceeding $6 \mathrm{~mm}$, thus the number of trees that need to be planted would be adjusted only slightly to account for mortality (less than $5 \%$ for both stock types). At Plowboy Bend CA, essentially $85 \%$ of the container stock compared to $35 \%$ of the bareroot stock had averaged $6 \mathrm{~mm}$ of diameter growth per year (Table 1). At the Cuivre Island CA, nearly all of the container stock compared to essentially $50 \%$ of the bareroot stock had averaged $6 \mathrm{~mm}$ of diameter growth per year (Table 2). Although survival was not evaluated in our study, Dey et al. (2004) reported third-year survival rates of 95 and $75 \%$ for the container and bareroot planting stock, respectively, at the Plowboy Bend CA. Assuming survival is similar at Cuivre Island CA, then the numbers of seedlings of each stock type that are needed to meet a target stocking goal of 300 trees $^{-h^{-1}}{ }^{\text {that }}$ are $>6 \mathrm{~cm}$ in dbh at age 10 are 340 container and 1130 bareroot seedlings. Because costs can vary considerably for planting stock, site preparation, hand- vs. machine-planting, weed control, and fertilization, it is difficult to determine which stock type would result in the least-cost approach.

Container planting stock does offer some advantages compared to traditional bareroot planting stock that may make it the preferred alternative even if not the least-cost approach (Grossman et al., 2003). Container seedlings with large intact root systems exhibit less transplant shock resulting in less mortality and more rapid growth as shown in this study. Large container seedlings are typically $>1.5 \mathrm{~m}$ tall, so their shoots are or will quickly be above the deer browse line and shading from herbaceous competition (Dey et al., 2004). When planting flood prone bottomlands, tall container seedlings are more likely to survive because their leaves are less likely to be fully inundated by spring flood waters (Hosner, 1960). The planting window for container stock is wider than for bareroot stock. Unlike bareroot stock, container stock can be fall-planted because seedlings are less likely to frost-heave (Van Sambeek et al., 1987). Because root elongation occurs from existing root tips, air- and chemically-root-pruned container stock can be planted later in the spring when flooding is less likely (Stanturf et al., 2004). There is some evidence container planting stock with very fibrous roots systems result in trees showing early flowering and heavier mast production which may be of considerable value to managers managing for wildlife (Dey et al., 2010; Grossman et al., 2003). Further, if container planting stock retains their higher growth rates beyond age 10, it will reduce rotation lengths for wood-based products resulting in improved liquidity of the investment.

\section{Conclusion}

Success in afforestation requires planting high-quality seedlings with large stem diameters and well-balanced root systems that use management practices (compatible cover crops and nurse crop trees) that promote survival and growth (Dey et al., 2010). Mariotti et al. (2015) report that in the last 15 years, many regionally important forest nurseries in Europe have converted from bareroot to container production. Repeated air-root-pruning of seedlings that are stepped up from shallow open-bottom containers to successively larger containers have the potential to produce larger seedlings with more fibrous root systems than bareroot seedlings in conventional nursery beds. Our study demonstrated that swamp white oak, when established from repeatedly air-root-pruned container planting stock on less than ideal oak sites (droughty or poorly drained with frequent flooding), has the 
capacity for faster height, diameter, and biomass growth than trees from bareroot planting stock. Seedlings produced that using the technique of repeated air-root pruning, potting media with high pore volumes, and frequent stepping up to larger open-bottom containers characteristically showed a high number of lateral (feeder) roots immediately below the root collar (Figure 2). These roots presumably help seedlings to quickly adapt to the site and initiate growth that can be sustained for multiple years after field planting (Figure 4). Although air-rootpruned container seedlings may not be the least-cost approach for timber production, their large size offers intrinsic advantages where bareroot planting stock is unlikely to lead to successful afforestation and restoration plantings.

\section{Acknowledgements}

We are indebted to Wayne Lovelace and the Forrest Keeling Nursery for sharing the details surrounding their patented Root Production Method (RPM ${ }^{\circledR}$ ) and supporting photographs. Also we thank Dan Dey, Ken Dalrymple, Kenny Bader, and the Missouri Department of Conservation for providing the early history and establishment records for each of the plantings and Bill Dijak for creating and modifying figures. Our work was funded through the University of Missouri Center for Agroforestry under a cooperative agreement with the EPA (C R 826704-01-0) and with the USDA Agricultural Research Service, Dale Bumpers Small Farms Research Center, Booneville, AR (AG-02100251) and through the USDA Forest Service, Northern Research Station for manuscript preparation. The results presented are the sole responsibility of the Principal Investigators and/or the University and may not represent the policies or positions of the EPA or USDA.

\section{References}

Amoroso, G., Frangi, P., Piatti, R., Ferrini, F., Fini, A., \& Faoro, M. (2010). Effect of Container Design on Plant Growth and Root Deformation of Little Leaf Linden and Field Elm. HortScience, 45, 1824-1829.

Arnold, M. A., \& Struve, D. K. (1989). Growing Green Ash and Red Oak in $\mathrm{CuCO}_{3}$-Treated Containers Increases Root Regeneration and Shoot Growth Following Transplant. Journal of the American Society of Horticulture Science, 114, 402406.

Bumgarner, M. L., Salifu, K. F., \& Jacobs, D. F. (2008). Subirrigation of Quercus rubra Seedlings: Nursery Stock Quality, Media Chemistry, and Early Field Performance. HortScience, 43, 2179-2185.

Davis, A. S., \& Jacobs, D. F. (2005). Quantifying Root System Quality of Nursery Seedlings and Relationship to Outplanting Performance. New Forests, 30, 295-311. http://dx.doi.org/10.1007/s11056-005-7480-y

Davis, A. S., Jacobs, D. F., Wightman, K. E., \& Birge, Z. K. D. (2006). Organic Matter Added to Bareroot Nursery Beds Influences Soil Properties and Morphology of Fraxinus pennsylvanica and Quercus rubra Seedlings. New Forests, 31, 293303. http://dx.doi.org/10.1007/s11056-005-7484-7

Dey, D. C., \& Parker, W. C. (1997). Morphological Indicators of Stock Quality and Field Performance of Red Oak (Quercus rubra L.) Seedlings Underplanted in a Central Ontario Shelterwood. New Forests, 14, 145-156. http://dx.doi.org/10.1023/A:1006577201244

Dey, D. C., Gardiner, E. S., Kabrick, J. M, Stanturf, J. A., \& Jacobs, D. F. (2010). Innovations in Afforestation of Agricultural Bottomlands to Restore Native Forests in the Eastern USA. Scandinavian Journal of Forest Research, 25, 31-42. http://dx.doi.org/10.1080/02827581.2010.485822

Dey, D. C., Jacobs, D., McNabb, K., Miller, G., Baldwin, V., \& Foster, G. (2008). Artificial Regeneration of Major Oak (Quercus) Species in the Eastern United States-A Review of the Literature. Forest Science, 54, 77-106.

Dey, D. C., Lovelace, W., Kabrick, J. M., \& Gold, M. A. (2004). Production and Early Field Performance of RPM ${ }^{\circledR}$ Seedl- $^{-}$ ings in Missouri Floodplains. In C. H. Michler, P. M. Pijut, J. W. Van Sambeek, M. V. Coggeshall, J. Siefert, et al., (Eds.), Black Walnut in a New Century. General Technical Report NC-243 (pp. 59-65). St. Paul, MN: North Central Research Station, USDA Forest Service. http://treesearch.fs.fed.us/pubs/14707

Dixon, R. K., Pallardy, S. G., Garrett, H. E., \& Cox, G. S. (1983). Comparative Water Relations of Container-Grown and Bare-Root Ectomycorrhizal and Nonmycorrhizal Quercus velutina Seedlings. Canadian Journal of Botany, 61, 15591565. http://dx.doi.org/10.1139/b83-168

Funk, D. T., Roth, P. L., \& Celmer, C. K. (1980). Influence of Container Type and Potting Medium on Growth of Black Walnut Seedlings. Research Note NC-253. St. Paul, MN: North Central Forest Experiment Station, USDA Forest Service. http://treesearch.fs.fed.us/pubs/11159

Goransson, H., Fransson, A. M., \& Jonsson-Belyazid, U. (2007). Do Oaks Have Different Strategies for Uptake of N, K, and P Depending on Soil Depth? Plant and Soil, 297, 119-125. http://dx.doi.org/10.1007/s11104-007-9325-2 
Groninger, J. W. (2005). Increasing the Impact of Bottomland Hardwood Afforestation. Journal of Forestry, 103, $184-188$.

Grossman, B. C., Gold, M. A., \& Dey, D. C. (2003). Restoration of Hard Mast Species for Wildlife in Missouri Using Precocious Flowering Oak in the Missouri River Floodplain, USA. Agroforestry Systems, 59, 3-10. http://dx.doi.org/10.1023/A:1026124717097

Grossnickle, S. C. (2005). The Importance of Root Growth in Overcoming Planting Stress. New Forests, 30, $273-294$. http://dx.doi.org/10.1007/s11056-004-8303-2

Haase, D. L. (2008). Understanding Forest Seedling Quality: Measurements and Interpretation. Tree Planters' Notes, 52, 24-30. http://www.rngr.net/publications/tpn/52-2

Haase, D. L., Rose, R., \& Trobaugh, J. (2006). Field Performance of Three Stock Sizes of Douglas-Fir Container Seedlings Grown with Slow-Release Fertilizer in the Nursery Growing Medium. New Forests, 31, 1-24. http://dx.doi.org/10.1007/s11056-004-5396-6

Hosner, J. F. (1960). Relative Tolerance of Complete Inundation for 14 Bottomland Tree Species. Forest Science, 6, 246-251.

Jacobs, D. F., \& Landis, T. D. (2009). Fertilization. In R. K. Dumroese, T. Luna, \& T. D. Landis (Eds.), Nursery Manual for Native Plants: A Guide for Tribal Nurseries. Volume 1: Nursery Management. Agriculture Handbook 730 (pp. 200-215). Washington DC: USDA Forest Service. http://npn.rngr.net/publications/tribal-nursery-manual

Kabrick, J. M., Dey, D. C., Van Sambeek, J. W., Wallendorf, M., \& Gold, M. A. (2005). Soil Properties and Growth of Swamp White Oak and Pin Oak on Bedded Soils in the Lower Missouri River Floodplain. Forest Ecology and Management, 204, 315-327. http://dx.doi.org/10.1016/j.foreco.2004.09.014

Kabrick, J. M., Dey, D. C., Van Sambeek, J. W., Coggeshall, M. C., \& Jacobs, D. F. (2012). Quantifying Flooding Effects on Hardwood Seedling Survival and Growth for Bottomland Restoration. New Forests, 43, 695-710.

http://dx.doi.org/10.1007/s11056-012-9331-y

Kurz, D. (2003). Trees of Missouri (pp. 276-277). Jefferson City, MO: Missouri Department of Conservation.

Landhausser, S. M., Rodriguez-Alvarez, J., Marenholtz, E. H., \& Lieffers, V. J. (2012). Effect of Stock Type Characteristics and Time of Planting on Field Performance of Aspen (Populus tremuloides Michx.) Seedlings on Boreal Reclamation Sites. New Forests, 43, 679-693. http://dx.doi.org/10.1007/s11056-012-9346-4

Landis, T. D., Tinus, R. W., McDonald, S. E., \& Barnett, J. P. (1990). Containers and Growing Media: Volume 2, The Container Tree Nursery Manual. Agricultural Handbook 674. Washington DC: USDA Forest Service.

http://www.rngr.net/publications/ctnm/volume-2

Lovelace, W. (1998). The Root Production Method (RPM) System for Producing Container Trees. Combined Proceedings of the International Plant Propagators Society, 48, 556-557.

Lovelace, W. (2002). Root Production Method System. In L. E. Riley, R. K. Dumroese, \& T. D. Landis (Technical Coordinators), National Proceedings: Forest and Conservation Nursery Associations-1999, 2000, and 2001. RMRS-P-24 (pp. 20-21). Fort Collins, CO: Rocky Mountain Research Station, USDA Forest Service.

Mariotti, B., Maltoni, A., Jacobs, D. F., \& Tani, A. (2015). Container Effects on Growth and Biomass Allocation in Quercus robur and Juglans regia Seedlings. Scandinavian Journal of Forest Research, 30, 401-415. http://dx.doi.org/10.1080/02827581.2015.1023352

McDonald, S. E., Tinus, R. W., Reid, C. P. B., \& Grossnickle, S. C. (1984). Effect of $\mathrm{CuCO}_{3}$ Container Wall Treatment and Mycorrhizae Fungi Inoculation of Growing Medium on Pine Seedling Growth and Root Development. Journal of Environmental Horticulture, 2, 5-8.

Nelson, W. R. (1998). Root Pruning Can Influence First Order Lateral Root Development of Containerized Plants. Combined Proceedings of the International Plant Propagators Society, 48, 96-103.

Oliet, J. A., \& Jacobs, D. F. (2012). Restoring Forests: Advances in Techniques and Theory. New Forests, 43, 535-541. http://dx.doi.org/10.1007/s11056-012-9354-4

Pinto, J. R., Marshall, J. D., Dumroese, R. K., Davis, A. S., \& Cobos, D. R. (2011). Establishment and Growth of Container Seedlings for Reforestation: A Function of Stocktype and Edaphic Conditions. Forest Ecology and Management, 261, 1876-1884. http://dx.doi.org/10.1016/j.foreco.2011.02.010

Ponder Jr., F., Kramer, M. J., \& Eivazi, F. (2008). Effect of Fertilizer Treatments on an Alkaline Soil and on Early Performance of Two Bottomland Oak Species. In D. F. Jacobs, \& C. H. Michler (Eds.), Proceedings of the 16th Central Hardwood Forest Conference. General Technical Report NRS-P-24 (pp. 552-558). Newtown Square, PA: Northern Research Station, USDA Forest Service. http://treesearch.fs.fed.us/pubs/14094

Rietveld, W. J., \& Van Sambeek, J. W. (1989). Relating Black Walnut Planting Stock Quality to Field Performance. In G. Rink, \& C. A. Budelsky (Eds.), Proceedings of the 7th Central Hardwood Forest Conference, General Technical Report NC-132 (pp. 162-169). St. Paul, MN: North Central Forest Experiment Station, USDA Forest Service.

http://treesearch.fs.fed.us/pubs/10196 
Rogers. R. (1990). Quercus bicolor Willd. Swamp White Oak. In R. M. Burns, \& B. H. Honkala (Technical Coordinators), Silvics of North America: 2. Hardwoods. Agricultural Handbook 654 (pp. 614-617). Washington DC: USDA Forest Service. http://www.na.fs.fed.us/spfo/pubs/silvics_manual/volume_2/quercus/bicolor.htm

Ruehle, J. L., \& Kormanik. P. P. (1986). Lateral Root Morphology: A Potential Indicator of Seedling Quality in Northern Red Oak. Research Note SE-344. Ashville, NC: Southeastern Forest Experiment Station, USDA Forest Service.

Rune, G. (2003). Slits in Container Wall Improve Root Structure and Stem Straightness of Outplanted Scots Pine Seedlings. Silva Fennica, 37, 333-342. http://dx.doi.org/10.14214/sf.493

Salifu, K. F., Jacobs, D. F., \& Birge, Z. K. D. (2009). Nursery Nitrogen Loading Improves Field Performance of Bareroot Oak Seedlings Planted on Abandoned Mine Lands. Restoration Ecology, 17, 339-349.

http://dx.doi.org/10.1111/j.1526-100X.2008.00373.x

Salifu, K. F., \& Jacobs, D. F. (2006). Characterizing Fertility Targets and Multi-Element Interactions in Nursery Culture of Quercus rubra Seedlings. Annals of Forest Science, 63, 231-237. http://dx.doi.org/10.1051/forest:2006001

Schultz, R. C., \& Thompson, J. R. (1990). Nursery Practices That Improve Hardwood Seedling Root Morphology. Tree Planters' Notes, 41, 21-32. http://www.rngr.net/publications/tpn/41-3

Schultz, R. C., \& Thompson, J. R. (1996). Effect of Density Control and Undercutting on Root Morphology of $1+0$ Bareroot Hardwood Seedlings: Five-Year Field Performance of Root-Graded Stock in the Central USA. New Forests, 13, 297310.

Shaw, G. W., Dey, D. C., Kabrick, J., Grabner, J., \& Muzika. R.-M. (2003). Comparison of Site Preparation Methods and Stock Types for Artificial Regeneration of Oaks in Bottomlands. In J. W. Van Sambeek, J. O. Dawson, F. Ponder Jr., E. F. Loewenstein, \& J. S. Fralish (Eds.), Proceedings of the 13th Central Hardwood Forest Conference. General Technical Report NC-234 (pp. 186-198). St. Paul, MN: North Central Research Station, USDA Forest Service.

South, D. B. (2008). Comments on Alternatives to Methyl Bromide for Quarantine Purposes in Forest Nurseries. In R. K. Dumroese, \& L. E. Riley (Technical Coordinators), National Proceedings of the Forest and Conservation Nursery Associations 2007. RMRS-P-57 (pp. 18-26). Fort Collins, CO: Rocky Mountain Research Station, USDA Forest Service.

Stanturf, J. A., Conner, W. H., Gardiner, E. S., Schweitzer. C. J., \& Ezell, A. W. (2004). Recognizing and Overcoming Difficult Site Conditions for Afforestation of Bottomland Hardwoods. Ecological Restoration, 22, 183-193. http://dx.doi.org/10.3368/er.22.3.183

Stanturf, J. A., Schoenholtz, S. H., Schweitzer, C. J., \& Shepard, J. P. (2001). Achieving Restoration Success: Myths in Bottomland Hardwood Forests. Restoration Ecology, 9, 189-200.

http://dx.doi.org/10.1046/j.1526-100x.2001.009002189.x

Struve, D. K. (1993). Effect of Copper-Treated Containers on Transplant Survival and Regrowth of Four Tree Species. Journal of Environmental Horticulture, 11, 196-199.

Timmer, V. R. (1996). Exponential Nutrient Loading: A New Fertilization Technique to Improve Seedling Performance on Competitive Sites. New Forests, 13, 275-295.

Tsakaldimi, M., Ganatsas, P., \& Jacobs, D. F. (2013). Prediction of Planted Seedling Survival of Five Mediterranean Species Based on Initial Seedling Morphology. New Forests, 44, 327-339.

http://dx.doi.org/10.1007/s11056-012-9339-3

Van Sambeek, J. W., \& Garrett, H. E. (2004). Ground Cover Management in Walnut and Other Hardwood Plantings. In C. H. Michler, P. M. Pijut, J. W. Van Sambeek, M. V. Coggeshall, J. Siefert et al. (Eds.), Black Walnut in a New Century. General Technical Report NC-243 (pp. 85-100). St. Paul, MN: North Central Research Station, USDA Forest Service.

http://www.treesearch.fs.fed.us/pubs/14714

Van Sambeek, J. W., Williams, R. D., \& Hanover, J. W. (1987). Comparison of Planting Methods for Nursery- and Container-Grown Black Walnut Seedlings. In R. L. Hay, F. W. Woods, \& H. DeSelm (Eds.), Proceedings of the 6th Central Hardwood Forest Conference (pp. 69-74). Knoxville, TN: University of Tennessee.

Walter, W. D., Godsey, L. D., Garrett, H. E., Dwyer, J. P., Van Sambeek, J. W., \& Ellersieck, M. (2013). Survival and 14-Year Growth of Black, White and Swamp White Oaks Grown as Bareroot and RPM ${ }^{\circledR}$-Containerized Planting Stock. Northern Journal of Applied Forestry, 30, 43-46.

Wenny, D. L., \& Woollen, R. L. (1989). Chemical Root Pruning Improves the Root System Morphology of Containerized Seedlings. Western Journal of Applied Forestry, 4, 15-17.

Whitcomb, C. (2001). Seedling Development: The Critical First Days. Combined Proceedings of the International Plant Propagators Society, 51, 610-614.

Wilson, B. C., \& Jacobs, D. F. (2006). Quality Assessment of Temperate Zone Deciduous Hardwood Seedlings. New Forests, 31, 417-433. http://dx.doi.org/10.1007/s11056-005-0878-8

Wood, B. W., \& Hanover, J. W. (1981). Accelerating the Growth of Black Walnut Seedlings. Tree Planters' Notes, 32, 35-38. http://www.rngr.net/publications/tpn/32-2 